\title{
Occurrence and Distribution of Polyphenolics in Species of Deguelia (Leguminosae)
}

Edson de Jesus Marques ${ }^{1}$, João Carlos da R Bastos Serafim², Bruno Brito Lemes ${ }^{2}$, Marly Fernandes A Carvalho², Madson de Godoi Pereira ${ }^{2}$ and Lourdes Cardoso de Souza Neta ${ }^{2 *}$

${ }^{1}$ Departamento de Ciências Exatas e da Terra , Universidade do Estado da Bahia, Alagoinhas, Bahia, Brazil ${ }^{2}$ Departamento de Ciências Exatas e da Terra I, Universidade do Estado da Bahia, Salvador, Bahia, Brazil

\begin{abstract}
The species of Deguelia (Papilonoidae Leguminose) genus are recognized for producing polyphenolic secondary metabolities that are predominantly classified as isoflavonoids. The study about the distribution of these secundary metabolities in species of Deguelia genus is very important for understanding the chemosystematic at genus level. Additionally, it has been reported that polyphenolics isolated from Deguelia present many desirable biological effects against human diseases and agricultural pests. Thus, this paper reviewed the occurrence and distribution of polyphenolics in species of Deguelia and evidenced the biological properties of these compounds.
\end{abstract}

Keywords: Deguelia (Papilonoidae Leguminosae); Polyphenolics; Leguminosae; Papilionoideae

\section{Introduction}

Deguelia genus belongs to Papilionoideae subfamily, Leguminosae family and comprises 20 species mainly distributed in South America $[1,2]$. Some of them are used by Amazon indigenous population due to its ictiotoxic properties, such as Deguelia duckeana, known as "cipó cururu" or "timbó" [3], D. utilis and D. rufescens var. urucu, commonly known as "timbó branco" and "timbó vermelho", respectively [4,5]. Their insecticide and ichthyotoxic activities are attributed to rotenoids presence in its roots [4]. Deguelia species are rich in polyphenolic which demonstrate many biological activities such as leishmanicidal [6], cytotoxic against Artemia salina [3], antitumoral [7], antioxidant [8], phytotoxicity [9], antimicrobial $[10,11]$ and vasorelaxant effect [12], among others. In this context, the aim of this paper is to review Deguelia polyphenolics and biological potential of their species.

\section{Deguelia species distribution in Brazil}

Seventeen brazilian Deguelia species are distributed into two sections, based on morphological characters, specially the number of eggs in the ovary: Deguelia sect. Multiovulis A.M.G. Azevedo comprises five species containing 7-15 eggs per ovary: Deguelia costata (Benth.) A. M. G. Azevedo \& R. A. Camargo, D. densiflora (Benth.) A. M. G. Azevedo ex M. Souza, D. hastchbachii (Benth.) A.M.G. Azevedo, D. longeracemosa (Benth.) A.M.G. Azevedo and D. spruceana (Benth.) A. M. G. Azevedo \& R. A. Camargo, while species with six eggs per ovary are allocated in Deguelia sect. Deguelia: D. amazonica Killip, D. angulata (Ducke) A.M.G. Azevedo \& R.A. Camargo, D. utilis (A. C. Sm.) A. M. G. Azevedo, D. scandens Aubl., D. negrensis (Benth.) Taub. [Magalhães], D. duckeana A. M. G. Azevedo, D. rariflora (Mart. ex Benth.) G. P. Lewis \& Acev.-Rodr., D. urucu (Killip \& A. C. Sm.) A. M. G. Azevedo \& R. A. Camargo, D. nitidula (Benth.) A. M. G. Azevedo \& R. A. Camargo, D. glaucifolia A. M. G. Azevedo, D. dasycalyx (Harms) A. M. G. Azevedo \& R. A. Camargo. Many of these species have Lonchocarpus sp and Derris sp. synonyms [1,2].

Among Multiovulis sect. species, three occur mainly in two brazilian regions: Southeastern, in the states Espírito Santo, Minas Gerais and Rio de Janeiro (D. costata, D. hatchibachii and D. longeracemosa) and Northern, in Amapá, Amazonas and Pará (D. densiflora and D. spruceana). However, D. spruceana was also found in the northern state of Maranhão [1,2].
The species Deguelia sect. is mainly distributed in the Northern states, being found in Pará, Roraima, Amapa, Rondônia, Amazonas and Acre. D. nitidula is one of the few Deguelia sect. species found in other regions such as Midwestern Goiás and Mato Grosso; Northeastern region in Maranhão and Piauí and Southeastern region in Minas Gerais and São Paulo. D. scandens is also found in Maranhão [1,2].

\section{Deguelia genus polyphenolics}

Deguelia species are rich in polyphenolics secondary metabolites such as chalcones, stilbenes, isoflavonoids (rotenoids, isoflavones, 4-hydroxy-3-phenylcoumarins, isoflavan and isoflavanones) and flavonoids derivatives (flavanones and dihydroflavanols).

\section{Rotenoids}

The review detected the presence of thirty four rotenoids in Deguelia species (Compounds 1-30 and 103-106, Figure 1). Deguelia sect. species was mainly isolated in Brazilian and Peruvian Amazon forest: D. utilis [13,14], D. negrensis [15], D. amazônica [16] and Cubé resin, formed by mixing $D$. utilis and D. rufescencs var. urucu [17]. Thedehydrorotenone (1) was also the only rotenoid isolated from Multiovulis section $D$. densiflora species [7]. These compounds were predominantly found in the roots, followed by the stems and aerial parts of these species. Rotenone (1) was the most widely distributed in Deguelia species (Figure 1).

\section{Stilbenes}

Currently, eighteen stilbenes (compounds 31-47 and 109, Figure 1) and their derivatives have been isolated from Deguelia genus. The

*Corresponding authors: Lourdes Cardoso de Souza Neta, Departamento de Ciências Exatas e da Terra I, Universidade do Estado da Bahia, Salvador, Bahia Brazil, Tel: 71 3117-2200; E-mail: Icsneta2@gmail.com

Received September 11, 2015; Accepted October 01, 2015; Published October 08, 2015

Citation: de Jesus Marques E, da R Bastos Serafim JC, Lemes BB, Carvalho MFA de Godoi Pereira M, et al. (2015) Occurrence and Distribution of Polyphenolics in Species of Deguelia (Leguminosae). J Microb Biochem Technol 7: 327-333. doi:10.4172/1948-5948.1000234

Copyright: (C) 2015 de Jesus Marques E, et al. This is an open-access article distributed under the terms of the Creative Commons Attribution License, which permits unrestricted use, distribution, and reproduction in any medium, provided the original author and source are credited. 


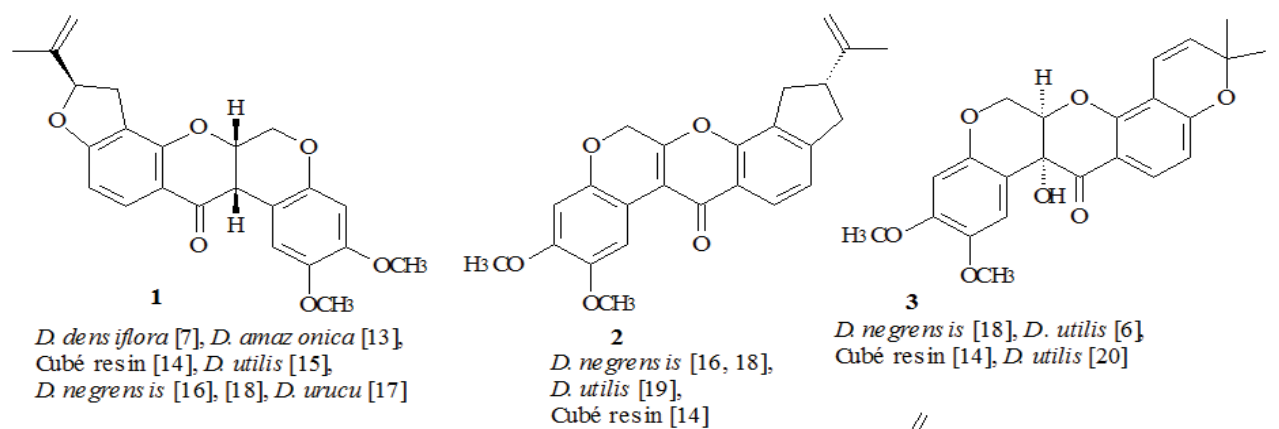

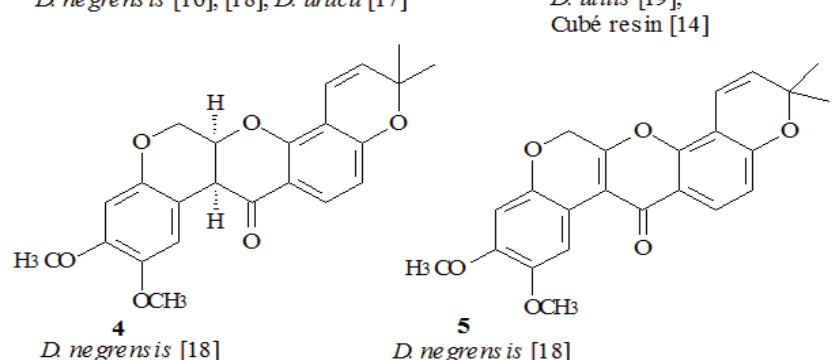

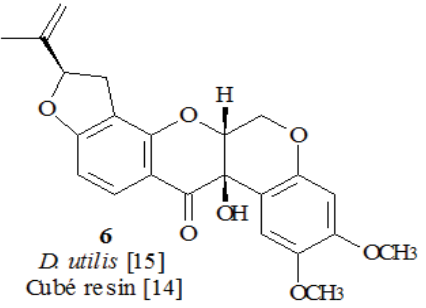

$$
\begin{aligned}
& \text { D. negrensis [18] } \\
& \text { Cubé resin [14] } \\
& \text { D. utilis [15] }
\end{aligned}
$$

D. negrens is $[18]$

Cubé resin [14]

$\mathrm{H} 3 \mathrm{CO}$

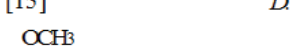

utilis [20]<smiles>[R2]c1cc2c(c3c1C(=O)[C@]1([R8])c4cc(OC)c(OC)cc4OC[C@H]1O3)C=CC(C)(C)O2</smiles><smiles>[R][C@]12COc3cc(C)c(C)cc3[C@@]1([R])Oc1c(ccc3c1C[C@@H](C(C)C)O3)C2=O</smiles><smiles></smiles>

\begin{tabular}{clc} 
& $\mathrm{R}_{1}$ & $\mathrm{R}_{2}$ \\
$\mathbf{1 2}-$ & $\mathrm{OCH}_{3}$ & $\mathrm{H}$ \\
$\mathbf{1 3}-$ & $\mathrm{OH}$ & $\mathrm{H}$ \\
$\mathbf{1 4}-$ & $\mathrm{OCH}$ & $\mathrm{H}$ \\
$\mathbf{1 5}-$ & $\mathrm{H}$ & $\mathrm{OH}$ \\
$\mathbf{1 6}-$ & $\mathrm{OH}$ & $\mathrm{OH}$ \\
\multicolumn{3}{c}{ Cubé resin $[14]$}
\end{tabular}

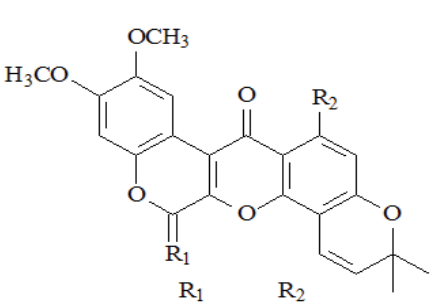

17- $2 \mathrm{H} \quad \mathrm{OH}$ Cubé resin [14]

18- $\quad \mathrm{O} \quad \mathrm{H}$ Cubé resin [14]

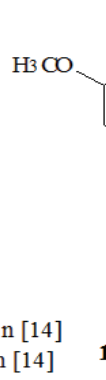

19 -<smiles>COc1ccc2c(c1)[C@]1(C)C(=O)c3ccc(C)c(C)c3OC1(C)CO2</smiles>

$\mathrm{R}$<smiles>Cc1ccoc1F</smiles><smiles>CC1CCCC1CO</smiles><smiles></smiles><smiles>CC(=O)CC(O/C(O)=C(/C)CC=C(C)C)C(CCl)(CCl)OC(C)=C(C)CO</smiles>

$\mathrm{OCH} 3$<smiles>CC(C)(C)c1ccc2c(c1)[C@]1(O)C(=O)c3ccc4c(c3O[C@H]1CO2)[C@@H](O)[C@H](O)C(C)(C)O4</smiles>

$\begin{array}{lll}\mathbf{2 4 -} & 4^{\prime} & 5^{\prime} \\ \mathbf{2 5 -} & 4^{\prime} & 5^{\prime} \\ \mathbf{2 6}- & 4^{\prime} & 5^{\prime} \\ \mathbf{2 7}- & 4^{\prime} & 5^{\prime} \\ \text { Cubé resin } & {[14]}\end{array}$<smiles>COc1cc2c(cc1OC)OC1C(=O)c3ccc(C)c(I)c3OC1CO2</smiles>

28 -<smiles>C=CC(C)C1CC(C)=C(C)O1</smiles><smiles>CC1=C(C)OC(C)(C)C=C1</smiles>

Cubé resin [14]

Cubé resin [14] 
Citation: de Jesus Marques E, da R Bastos Serafim JC, Lemes BB, Carvalho MFA, de Godoi Pereira M, et al. (2015) Occurrence and Distribution of Polyphenolics in Species of Deguelia (Leguminosae). J Microb Biochem Technol 7: 327-333. doi:10.4172/1948-5948.1000234<smiles>[R]Oc1cccc(/C=C/c2ccc(OC)c(CC=C(C)C)c2)c1</smiles>

$31-\mathrm{R}=\mathrm{H}, D$. nitidula [17], D. rariflora [21] $32-\mathrm{R}=\mathrm{OCH}_{3}$, D. nitidula [17], D. duckeana [3] $34-\mathrm{R}=\mathrm{OH}, D$. hats chbachii $[10]$<smiles>[R]c1c(OC)cc(/C=C/c2ccc3c(c2)C=CC(C)(C)O3)cc1OC</smiles>

$36-\mathrm{R}=\mathrm{OCH}_{3}, D$. rufes cens [9], D. utilis [4] $37-\mathrm{R}=\mathrm{H}, D$. rufescens $[5,9]$, D. utilis $[5,20,23]$<smiles>[R10]Oc1cc(/C=C\c2ccc(OCC=C(C)C)cc2)cc(O[R10])c1</smiles>
D. utilis [6]<smiles>[R]c1ccc(/C=C/C(=O)c2ccc3c(c2OC)C=CC(C)(C)O3)cc1[R3]</smiles>

$48-\mathrm{R}_{1}=\mathrm{R}_{2}=\mathrm{R}_{3}=\mathrm{H}$, D. duckeana $[3]$ $49-\mathrm{R} 1=\mathrm{R} 3=\mathrm{H} ; \mathrm{R} 2=\mathrm{OH}, D$. duckean $a[3]$ D. nitidula [17], Cubé resin [22]<smiles>C=CC(C)(C)C</smiles>

33 - D. hats chbachi
Cubé res in [22]

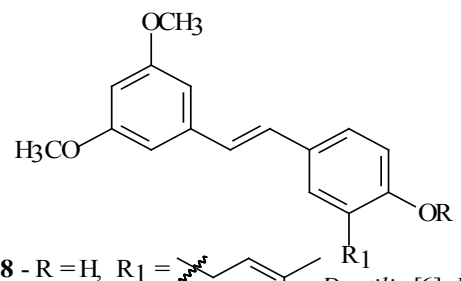

$38-\mathrm{R}=\mathrm{H}, \mathrm{R} 1=$ D. utilis [6], D. rufescens [9] $39-\mathrm{R}=\mathrm{R}_{1}=\mathrm{H}$ D. utilis [6], D. rufescens $[5,9]$ $40-\mathrm{R}=\mathrm{R}_{1}=\mathrm{H}$, D. rufescens $[9]$<smiles>COc1cc(O)cc(/C=C/c2ccc(OCC=C(C)C)cc2)c1</smiles><smiles>COc1cc(/C=C/c2ccc(O)cc2)cc2c1OC(C)(C)C=C2</smiles>

47 - Cubé resin [22] D. nitidula [21]<smiles>CC(C)=CCOc1ccc(C(=O)/C=C/c2ccccc2)c(O)c1</smiles>

51 - D. duckeana [3]

$50-\mathrm{R} 1=\mathrm{H} ; \mathrm{R}_{2}=\mathrm{R}_{3}=\mathrm{OH}, D$. nitidula $[17]$<smiles>CCOc1cc(/C=C/C(=O)c2ccc3c(c2O)C=CC(C)(C)O3)ccc1O</smiles>

52 - Cubé resin [22] Cubé res in [22]$$
44-\mathrm{R}_{1}=\mathrm{R}_{2}=\mathrm{OCH}_{3}, \mathrm{R}_{3}=\mathrm{OH}, \mathrm{R}_{4}=\mathrm{H}
$$$$
\text { 45- } \mathrm{R}_{1}=\mathrm{H}, \mathrm{R}_{2}=\mathrm{R}_{3}=\mathrm{R}_{4}=\mathrm{OCH}_{3}
$$$$
46-\mathrm{R}_{1}=\mathrm{OCH}_{3}, \mathrm{R}_{2}=\mathrm{R}_{4}=\mathrm{H}_{3} \mathrm{R}_{3}=\mathrm{OH}
$$<smiles>C=C(C)C1Cc2cc3c(=O)c(-c4ccc5c(c4)OCO5)coc3cc2O1</smiles><smiles>CCCCOc1cc(OC)c2c(=O)c(-c3ccc(OCC=C(C)C)c(OCC=C(C)C)c3)coc2c1</smiles>

53 - D. dens iflora [24]

54 - D. densiflora [24]<smiles>CC1(C)C=Cc2c(cc(O)c3c(=O)c(-c4ccc5c(c4)OCO5)coc23)O1</smiles>

55 - D. spruceana [25], D. hats chbachii [10],

D. longeracemos a [11]<smiles>CC=CCc1c2c(c3occ(-c4ccc(O)cc4)c(=O)c3c1O)C=CC(C)(C)O2</smiles><smiles>CCOc1ccc(-c2coc3cc(OC)ccc3c2=O)cc1</smiles>

$56-\mathrm{R}=\mathrm{H}$, os ajin, $D$. longeracemos $a$ [11]

58 - D. longeracemos $a[11]$ $57-\mathrm{R}=\mathrm{CH}_{3}$, scandinone, $D$. hats chbachii $[10]$

J Microb Biochem Technol

ISSN: 1948-5948 JMBT, an open access journal

Volume $7(6): 327-333(2015)-329$ 
<smiles>CCOc1ccc(-c2coc3cc4c(c(O)c3c2=O)C=CC(C)(C)O4)cc1</smiles>

$\mathbf{5 9}-\mathrm{R}=\mathrm{H}$, D. densiflora $[7]$ $\mathbf{6 0}-\mathrm{R}=\mathrm{CH}_{3}$, D. densiflora $[7]$<smiles>C=C(C)C1Cc2c(cc3oc(=O)c(-c4ccc5c(c4)OCO5)c(OC)c3c2OC)O1</smiles>

62 - D. densiflora $[24]$

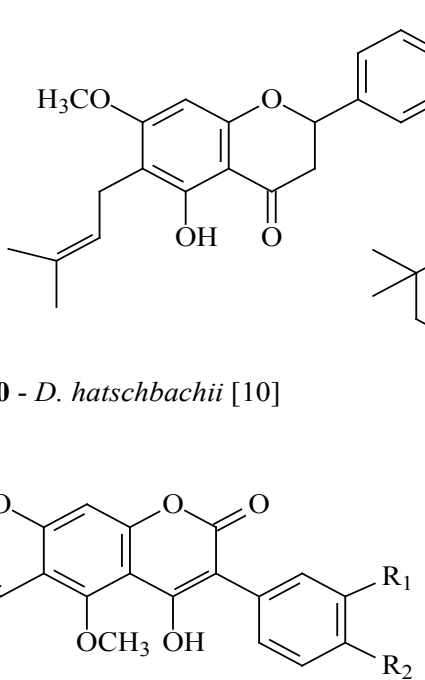

69- $\mathrm{R}_{1}=\mathrm{OH} ; \mathrm{R}_{2}=\mathrm{OCH}_{3}$, D. longeracemosa $[11]$

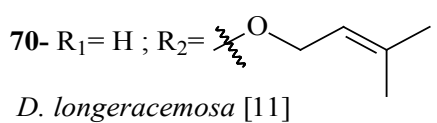

71- $\mathrm{R}_{1}, \mathrm{R}_{2}=-\frac{\xi}{\xi} \mathrm{OCH}_{2} \mathrm{O}-\xi$. longeracemosa $[11]$ 72- $\mathrm{R}_{1}=\mathrm{H} ; \mathrm{R}_{2}=\mathrm{OCH}_{3}$, D. longeraccemosa [11] D. hatschabachii [11]<smiles>COc1ccc([C@H]2Oc3cc(OC)c(CC=C(C)C)c(O)c3C(=O)[C@H]2O)cc1O</smiles>

82- D. rufescens $[8,12]$<smiles>COc1cc(OC)c(-c2coc3c4c(ccc3c2=O)OC(C)(C)C=C4)cc1OC</smiles><smiles>[R]Oc1c(-c2ccc3c(c2)OCO3)c(=O)oc2c3c(cc(OC)c12)OC(C)(C)C=C3</smiles>

$63-\mathrm{R}=\mathrm{H}$, D. spruceana [25] D. longeracemosa [11] $\mathbf{6 4}-\mathrm{R}=\mathrm{CH}_{3}$, D. spruceana $[25]$<smiles>[R]c1ccc(-c2c(O)c3c(OC)c([R])c4c(c3oc2=O)C=CC(C)(C)O4)cc1[R]</smiles>

65- $\mathrm{R}_{1}=$; $; \mathrm{R}_{2}=\mathrm{H} ; \mathrm{R}_{3}=\mathrm{OH}$,

D. spruceana [25], D. hatschabachii [10], D. longeracemosa [11]

$66-\mathrm{R}_{1}=$;

D. longeracemosa [11]

67- $\mathrm{R}_{1}=$; $; \mathrm{R}_{2}, \mathrm{R}_{3}=\frac{\xi}{\xi} \mathrm{OCH}_{2} \mathrm{O}-$

D. longeracemosa [11]

$68-\mathrm{R}_{1}=$ ? $; \mathrm{R}_{2}=\mathrm{H} ; \mathrm{R}_{3}=\mathrm{OH}$

D. longeracemosa [11]<smiles>[R20]c1cc2c(c(O)c1CC=C(C)C)C(=O)C[C@@H](c1ccccc1)O2</smiles>

75- $\mathrm{R}=\mathrm{Me}$

D. rariflora [21]

73 - D. hatschabachii [10]<smiles>[R4]c1ccc(C2CC(=O)c3c([Z])c(CC=C(C)C)c4c(c3O2)C=CC(C)(C)O4)cc1[R4]</smiles>

76- $\mathrm{R}_{1}=\mathrm{OH} ; \mathrm{R}_{2}=\mathrm{OMe} ; \mathrm{R}_{3}=\mathrm{OMe}$, 77- $\mathrm{R}_{1}=\mathrm{OH} ; \mathrm{R}_{2}=\mathrm{OH} ; \mathrm{R}_{3}=\mathrm{OMe}$ 78- $\mathrm{R}_{1}=\mathrm{OH} ; \mathrm{R}_{2}=\mathrm{OMe} ; \mathrm{R}_{3}=\mathrm{OH}$ 79- $\mathrm{R}_{1}=\mathrm{H} ; \mathrm{R}_{2}=\mathrm{OMe} ; \mathrm{R}_{3}=\mathrm{OMe}$ Cubé resin [22]<smiles>C=CC(C)(C)CC</smiles><smiles>CC(C)=CCC1=C2OC(c3ccc(O)cc3)CC(=O)C2=C(O)c2ccc1o2</smiles>

81 - D. hatschbachii [10] 
<smiles>COc1ccc([C@H]2Oc3cc4c(c(OC)c3C(=O)C2O)C=CC(C)(C)O4)cc1OC</smiles>

83- $\mathrm{R}_{1}=\mathrm{R}_{2}=\mathrm{CH}_{3}$

84- $\mathrm{R}_{1}=\mathrm{CH}_{3} ; \mathrm{R}_{2}=\mathrm{H}$,

D. rufescens [8]

85- $\mathrm{R}_{1}=\mathrm{R}_{2}=\mathrm{H}, D$. rufescens $[8,26]$<smiles>COc1ccc([C@@H]2CC(=O)c3c(cc4c(c3O)C=CC(C)(C)O4)O2)cc1O</smiles>

91 - D. rufescens [26]<smiles>COc1ccc(C2COc3c(ccc4c3C=CC(C)(C)O4)C2=O)c(OC)c1</smiles>

94 - Cubé resin [22]<smiles>COc1c(CCC(C)C)c(O)c2c(c1C(=O)C(=O)c1ccc(O)cc1)C=CC(C)(C)O2</smiles>

98 - D. longeracemosa [11]<smiles>[R1]c1ccc(C(=O)C(=O)c2c(O)cc3c(c2OC)C=CC(C)(C)O3)cc1[R]</smiles>

99- $\mathrm{R}_{1}=\mathrm{H} ; \mathrm{R}_{2}=\mathrm{OCH}_{3}$

100- $\mathrm{R}_{1}, \mathrm{R}_{2}=\mathrm{OCH}_{2} \mathrm{O}$

D. longeracemosa [11]
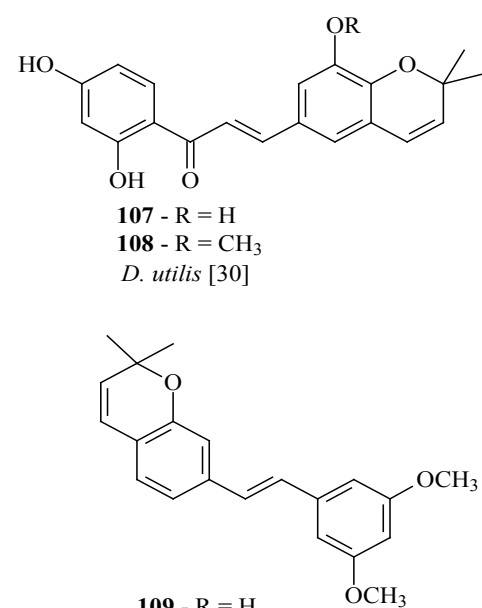

$108-\mathrm{R}=\mathrm{CH}_{3}$

D. utilis [23]<smiles>[R]C1C(=O)c2c(O)c(CC=C(C)C)c(OC)c(CC=C(C)C)c2O[C@H](c2ccc(OC)c(O)c2)C1[R]</smiles>

86- $\mathrm{R}=3$ beta $\mathrm{OH}$

87- $\mathrm{R}=\mathrm{H}$<smiles>C/C=C\Cc1c(OC)cc2c(c1O)C(=O)C(O)[C@H](c1ccc(OC)c(O)c1)O2</smiles>

92

92 - D. rufescens [26]<smiles>COc1cc(OC)c(C2COc3c(ccc4c3C(O)C(O)C(C)(C)O4)C2=O)cc1OC</smiles>

93 - D. amazonas [17]<smiles>CC1CCCCC1</smiles><smiles>[Y]C(C(=O)c1c(O)c2c(c(CCC(C)C)c1OC)OC(C)(C)C=C2)c1ccc(O)cc1</smiles>

96- $\mathrm{R}=\mathrm{H}$

97- $\mathrm{R}=\mathrm{CH}_{2} \mathrm{COCH}_{3}$<smiles>COc1ccc(CC(=O)c2c(O)cc3c(c2OC)C=CC(C)(C)O3)cc1</smiles>

101 - D. longeracemosa [11] $\mathrm{OCH}_{3}$<smiles>COc1c(CC=C(C)C)c2c(c3c1C(=O)C(C(C)=O)(c1ccc(O)cc1)C(C(C)=O)C3=O)C=CC(C)(C)O2</smiles>

102 - D. hatschbachii $[10]$<smiles>[2H]C12C(=O)c3ccc4c(c3O[C@H]1COc1cc(OC)c(C)cc12)CCC(C)(CI)O4</smiles>

103- $\mathrm{R}_{1}=\mathrm{R}_{2}=\mathrm{H} \quad \mathrm{OCH}_{3}$

$104-\mathrm{R}_{1}=\mathrm{H}, \mathrm{R}_{2}=\mathrm{OH}$

$105-\mathrm{R}_{1}=\mathrm{OH}, \mathrm{R}_{2}=\mathrm{H}$

$106-\mathrm{R}_{1}=\mathrm{R}_{2}=\mathrm{OH}$

D. utilis [30]<smiles>COc1cc(/C=C/c2ccc3c(c2)OC(C)(C)CC3)cc(OC)c1</smiles><smiles>[R1]Oc1cc(/C=C/C(=O)C2=C(O)CC(O)C=C2)cc2c1OC(C)(C)C=C2</smiles>

Figure 1: Molecular structures (1-111) of the polyphenolics found in Deguelia genus. 
Citation: de Jesus Marques E, da R Bastos Serafim JC, Lemes BB, Carvalho MFA, de Godoi Pereira M, et al. (2015) Occurrence and Distribution of Polyphenolics in Species of Deguelia (Leguminosae). J Microb Biochem Technol 7: 327-333. doi:10.4172/1948-5948.1000234

compounds (31-33) and (35-47) were isolated from Deguelia sect. species: D. nitidula [18], D. rariflora [19], D. duckeana [3], D. utilis $[4,14], D$. rufescens var. urucu [9] and Cubé resin (D. utilis and D. rufescens var. urucu) [20], while only three compounds were isolated from Multiovulis section species, (33) and (34), from D. hatschbachii [10] and compound (35) from D. spruceana [21]. These compounds were mainly found in roots and leaves of plants from Amazon forest. The exception was for $D$. hatschbachii, which was collected in Campinas, SP. The stilbenes (31), (32), (33), (35), (36), (37) and (38) were found in at least two different Deguelia genus species. Except for compound (40), all the other stilbene derivatives are prenylated.

\section{Chalcones}

The occurrence of prenylated chalcones derivatives in ring $\mathrm{B}$ (compounds 48-52 and 107-108, Figure 1) was only reported in $D$. duckeana [3], D. nitidula [18], Cubé resin (D. utilis and D. rufescens var. urucu) [20], all of them belonging to Deguelia sect. species.

\section{Isoflavones}

A total of nine isoflavones (compounds 53-61, Figure 1) have been reported in Deguelia plants. These ones were widespread in D. densiflora [22], D. spruceana [22], D. hatschbachii [10] and D. longeracemosa [11], all of Multiovulis sect. Only lonchocarpusone (61) was reported in D. utilis [23], Deguelia sect. The compounds predominant isolation was in the roots except for glabrescione (53) and glabrescione B (54) which was found in $D$. densiflora seeds.

\section{4-Hydroxy-3-phenylcoumarins}

The twelve prenylated derivatives in 4-hydroxy-3-phenylcoumarins ring A (compounds 62-73, Figure 1 ) were only reported in D. densiflora [24], D. spruceana [25], D. longeracemosa [11] and D. hatschbachii [10], all of them belonging to the Multiovulis sect. These ones were mainly detected in the roots and showed lower occurrence in seeds as glabrescin (62) which was isolated from $D$. densiflora seeds [21].

\section{Flavanones and dihydroflavanols}

Flavanones (79-81), (87) and (89) (Figure 1) and dihydroflavanols (82-86), (88) e (90-92) (Figure 1) were identified in Deguelia genus. Only these compounds have a flavonoid skeleton. The derivatives of flavanones (75-80 and 82-92) were reported in D. rariflora [19], D. rufescens var. urucu $[8,12], D$. utilis [4] and roots of Cubé resin (D. utilis e D. rufescens var. urucu) [20] from Deguelia sect. Yet, the compounds (80) and (81) were isolated from D. hatschbachii Multiovulis sect. roots [10]. Every compound structure showed preny and/or 2,2dimethylchromene in carbon 6 and hydroxyl and/or methoxyl group in carbon 5 , in ring $\mathrm{A}$.

\section{Isoflavanones and isoflavan}

These classes of secondary metabolites are rarely found in the Deguelia genus. The derivative of isoflavan (93) (Figure 1) was obtained from wood of D. amazonas Deguelia sect. [18]. Two derivatives of isoflavanones (94) and (95) (Figure 1) were reported in Cubé resin $(D$. utilis and D. rufescens var. urucu), both of Deguelia sect. [20].

\section{Ethanediones and deoxybenzoin}

Oxidized derivatives of stilbene as ethanediones and deoxybenzoin were only reported only in Multiovulis sect. plants (Compounds 96101, Figure 1). The compounds (96) and (97) were isolated from $D$. hatschbachii [10] and (98-101) of D. longeracemosa roots [11].

\section{4-hydroxy-3-phenylcoumarin derivative}

The scandenin alkylated derivative in C-3 (102, Figure 1) was isolated from $D$. hatschbachii roots. This compound is $\beta$-keto tautomer which corresponds to C-3 substituent ester.

\section{Coumarononochromones}

Only two derivatives of coumarononochromones (110 and 111, Figure 1) were isolated from roots of D. utilis, Deguelia sect. [14].

The most characteristic classes of secondary metabolites with predominant occurrence were distributed in two sections of Deguelia genus as rotenoid, stilbene and chalcone derivatives, in Deguelia sect. species and 4-hydroxy-3-phenylcoumarins, isoflavones, ethanediones and deoxybenzoin derivatives in Multiovulis sect. species. These are in agreement with the previous phytochemical studies on Deguelia species [10]. Rotenone (1) and scandenin (65) are the most representative compounds for the Deguelia and Multiovulis sections, respectively. The isoflavone derivatives are biosynthetic precursors of both rotenoids as 4-hydroxy-3-phenylcoumarins [24]. This demonstrates that species from both sections should be presumably endowed with strongly oxidizing enzymes [25]. Research about polyphenolic distribution in literature such as isoflavonoids and chalcones in species of a genus may help distinguish the evolution phase of its species [26].

\section{Biological potential of Deguelia species}

Deguelia species, which come from Peruvian and Brazilian Amazon and also other parts of Brazil, had their biological potential evaluated on the basis of extracts and compounds (molecular structures of these compounds are in Figure 1) which have been isolated from different species of this genus. In this survey, ten experimental models used to evaluate the potential of the control Deguelia the application of biological activities were recorded. Roots ethanolic extract from D. amazonica presented $3.7 \%$ of rotenone (1) (Figure 1) in its composition, showed toxicity to Cerotoma arcuatus (bean insect) when incorporated by contaminated leaves ingestion, by contact with contaminated surface and by topical application [16]. It is more effective for the first condition with adult mortality higher than $80 \%$ at $3.0 \%$ concentration $\mathrm{v} / \mathrm{v}$ [13]. Flavonoids (76-79) and stilbenes (44-46) isolated from the roots of the natural insecticide Cubé resin [20] (D. utilis and D. rufescencs var. urucu), showed inhibitory activity for NAD / ubiquinone oxidoreductase enzymes and ornithine decarboxylase (ODC) with $\mathrm{IC}_{50}$ ranging from 4.9 to 0.68 and 7.4 to $3.9 \mu \mathrm{M}$, for flavonoids and stilbenes, respectively, which was the best result for flavonoid (78) to the two enzymes, followed by $(\mathbf{7 6}, 77$ and 79) (Figure 1). The presence of dimethylpyran ring seems to be a key factor for these compounds activity, just like the $\mathrm{OH}$ in $\mathrm{C} 3$ position seems to be the differentiating factor for (78). Besides these ones, Fang and Casida, in 1999 [17], isolated and evaluated other compounds in the same kind of Cubé resin, the rotenoids $(1,3,4$ and 7$)$ and twentyfive derivatives (2, 10 to 30) [14]. Rotenone (1) and deguelina (4) were the most active, showing $\mathrm{IC}_{50} 0.0044$ and $0.0069 \mu \mathrm{M}$, respectively. Still regarding enzymatic activity, Pereira et al. [5] reported lonchocarpene (37) and 3,5- dimethoxy -4' -O- prenyl -trans- stilbene (39) inhibitory action for in vitro $\alpha$-glucosidase with $\mathrm{pIC}_{50}$ of $5.68 \pm 0,12$ and 5.73 \pm 00:08, respectively, target used to control type 2 diabetes. However, only (39) was able to reduce induced hyperglycemia in rats. Fang and Casida [20] also reported anti-tumor activity for flavonones (49, 77-79, 94 and 95) and in vitro stilbenes (44-46) to MCF 7 and Hepa $1 \mathrm{clc} 7$ cells strains. $\mathrm{IC}_{50}$ ranged between 0.34 and $30.0 \mu \mathrm{M}$, in which compound (94) showed the best results 1.9 and $0.34 \mu \mathrm{M}$, for each of the strains, respectively. Current research aimed at fighting the tumor 
Citation: de Jesus Marques E, da R Bastos Serafim JC, Lemes BB, Carvalho MFA, de Godoi Pereira M, et al. (2015) Occurrence and Distribution of Polyphenolics in Species of Deguelia (Leguminosae). J Microb Biochem Technol 7: 327-333. doi:10.4172/1948-5948.1000234

cell activities go through signaling mechanisms control. In this sense, Lui et al. [7] reported isoflavones inhibitory activity (59) and (60) regarding hypoxia inducing factor, HIF -1, for human breast tumor T47D cell, a key factor for solid tumors combat, showing $\mathrm{IC}_{50}=0.6 \mu \mathrm{M}$ and $5.0 \mu \mathrm{M}$, respectively. For Artemia salina toxicity test Magalhães et al. [10] assessed the compounds $(\mathbf{6 5}, \mathbf{8 0}$ and $\mathbf{8 1})$, finding $\mathrm{LC}_{50} 4.37$; 0.0004 and $13.1 \mu \mathrm{g} \mathrm{mL}^{-1}$, respectively. Magalhães et al. [10,11] evaluated the antimicrobial activity in bioautography assay for compounds (33, $34,56,63,65,66,73,80,81,97,99,102)$. Compounds (65 and 66) showed activity against Staphylococcus aureus and Bacillus subtilis and compounds $(\mathbf{6 3}, 71$ and 98) only for B. subtilis. Additionally, Lobo et al. [9] reported allelopathic compounds (36-40), which maximum inhibition germination did not exceed $20 \%$ of seeds from Mimosa pudica. However, when evaluated in pairs, the effect was higher, showing synergistic activity between compounds. On the other hand, Silva et al. [27-30] showed the opposite effect, lower activity for compounds $(\mathbf{8 3}, 84$ and 85$)$ when evaluated in pairs. As antioxidant activity, Lobo et al. [8] assessed the compounds (82-85) by DPPH method and all compounds showed small activity. Compound (82) produced $40 \pm 4.4$ $\%$ of the relaxing effect on rat aorta at $100 \mu \mathrm{M}$ concentration as shown by Mendes et al. [12]. Finally, it can still be reported the compounds neuroprotective activity ( 86 to $\mathbf{9 0}$ ) and ( 36 and $\mathbf{3 7}$ ) by Oliveira et al. [4].

\section{Conclusion}

Based on these phytochemical studies results we suggest the presence of secondary metabolites as oxidized stilbenes derivatives such as ethanediones and deoxybenzoin only in Multiovulis species and chalcones derivatives only in Deguelia sect. indicating that species in Multiovulis is more evolved than in Deguelia sect. Moreover, it was evidenced that flavonoids, stilbenes, isoflavones and rotenoids, isolated from Deguelia, present high biological potential, thus highlighting the necessity of new researches in order to achieve a better understanding about the secondary metabolites of Deguelia genus.

\section{References}

1. Camargo RA, Tozzi AMGA (2014) A synopsis of the genus Deguelia (Leguminosae, Papilionoideae, Millettieae) in Brazil. Brittonia 66: 12-32.

2. Tozzi AMGA (1989) Estudos taxonômicos dos gêneros Lonchocarpus Kunth e Deguelia Aubl. SP: 348.

3. Lima NM, Andrade JI, Lima KC, dos Santos FN, Barison A, et al. (2013) Chemical profile and biological activities of Deguelia duckeana A.M.G. Azevedo (Fabaceae). Nat Prod Res 27: 425-432.

4. Oliveira DG, Almeida CMC, Silva Consuelo YY (2012) Flavonoids from the Leaves of Deguelia utilis (Leguminosae): Structural Elucidation and Neuroprotective Properties. Journal of the Brazilian Chemical Society 23: 1933-1939.

5. Pereira AC, Arruda MS, da Silva EA, da Silva MN, Lemos VS, et al. (2012) Inhibition of Ît-glucosidase and hypoglycemic effect of stilbenes from the Amazonian plant Deguelia rufescens var. urucu (Ducke) A. M. G. Azevedo (Leguminosae). Planta Med 78: 36-38.

6. Fuchino H, Kiuchi F, Yamanaka A, Obu A, Wada H, et al. (2013) New leishmanicidal stilbenes from a Peruvian folk medicine, Lonchocarpus nicou. Chem Pharm Bull (Tokyo) 61: 979-982.

7. Lui Yang, Veena CK, Morgan JB, Mohammed KA, Jekabsons MB, et al. (2009) Methylalpinumisoflavone inhibits Hypoxia-inducible Factor-1 (HIF-1) activation by simultaneously targeting multiple pathways. The Journal of Biological Chemistry 284: 5859-5868.

8. Lôbo LT, Silva GA, Ferreira M (2009) Dihydroflavonols from the leaves of Derris urucu (Leguminosae): Structural Elucidation and DPPH Radical-Scavenging Activity. Journal of the Brazilian Chemical Society 20: 1082-1088.

9. Lobo LT, Silva GA, Freitas MC (2010) Stilbenes from Deguelia rufescens var. urucu (Ducke) A. M. G. Azevedo Leaves: Effects on Seed Germination and Plant Growth. Journal of the Brazilian Chemical Society 21: 1838-1844.
10. Magalhães AF, Tozzi AM, Magalha s EG, de Souza Moraes VR (2001) Prenylated flavonoids from Deguelia hatschbachii and their systematic significance in Deguelia. Phytochemistry 57: 77-89.

11. Magalhães AF, Tozzi AM, Magalhães EG, Souza-Neta LC (2006) New prenylated metabolites of Deguelia longeracemosa and evaluation of their antimicrobial potential. Planta Med 72: 358-363.

12. Mendes LJ, Capettini LS, Lôbo LT, da Silva GA, Arruda MS, et al. (2011) Endothelial nitric oxide-dependent vasorelaxant effect of isotirumalin, a dihydroflavonol from Derris urucu, on the rat aorta. Biol Pharm Bull 34: 14991500 .

13. Lawson MA, Kaouadji M, Allais DP, Champavier Y, Chulia AJ (2006) Substituted tubaic acids, new oxidative rotenoid metabolites from Lonchocarpus nicou. Tetrahedron Letters 47: 451-454.

14. Lawson MA, Kaouadji M, Chulia AJ (2010) A single chalcone and additiona rotenoids from Lonchocarpus nicou. Tetrahedron Letters 51: 6116-6119.

15. Vasconcelos MNL, Maia JGS (1976) Chemical study of Derris negrensis. Acta Amazonica 6: 59-61.

16. Alecio MR, Fazolin M, Coelho NRA, Catani V (2010) Ação inseticida do extrato de Derris amazonica Killip para Cerotoma arcuatus Olivier (Coleoptera: Chrysomelidae). Acta Amazonica 40: 719-728.

17. Fang N, Casida JE (1999) Cubé resin insecticide: identification and biological activity of 29 rotenoid constituents. J Agric Food Chem 47: 2130-2136.

18. Braz Filho R, Gottlieb OR, Mourão AP, Rocha Al e Oliveira FS (1975) Flavonoids from Derris species. Phytochemistry 14: 1454-1456.

19. Braz Filho R, Gottlieb OR, Mourão AP (1975) A stilbene and two flavanones from Derris rariflora. Phytochemistry 14: 261-263.

20. Fang N, Casida JE (1999) New bioactive flavonoids and stilbenes in Cubé Resin Insecticide. Journal of Natural Products 62: 205-210.

21. Delle-Monache MF, Valera GC, Sialer ZD, Marini-Bettolo GB (1977) 3-Aril-4methoxycoumarins and isoflavones from Derris glabrescens. From Gazetta Chimica Italiana 107: 403-407.

22. Garcia M, Kano MHC, Vieira DM, Nascimento MC e Mors WB (1986) Isoflavonoids from Derris spruceana. Phytochemistry 10: 2425-2427.

23. Kaouadji M, Agban A, Mariote AM (1986) Lonchocarpene, a stilbene, and lonchocarpusone, an isolavone: two new pyranipolyphenols from Lonchocarpus nicou roots. Journal of Natural Products 2: 281-285.

24. Apaecida M, Gagnin H, Gottlieb OR (1978) Isoflavonoids as systematic markers. Biochemical Systematics and Ecology 6: 225-238.

25. Gomes CMR, Gottlieb OR, Bettolo GBM, Delle Monache F, Polhill RM (1981) Systematic significance of flavonoids in Derris and Lonchocarpus. Biochemical Systematics and Ecology 9: 129-147.

26. Koes RE, Quattrocchio F, Mol JNM (1994) The flavonoid biosynthetic pathway in plants: Function and evolution. BioEssays 16: 123-132

27. Silva EA, Lôbo LT, Silva GA, Souza Filho AP, Da Silva MN, et al. (2013) Flavonoids from leaves of Derris urucu: Assessment of potential effects on seed germination and development of weeds. An Acad Bras Cienc 85: 881889.

28. Braz Filho R, Figueiredo US, Gottlieb OR, Mourão AP (1980) Rotenóides em Lonchocarpus longifolius. Acta amazônica 10: 843-844.

29. Lawson MA, Kaouadji M, Chulia AJ (2008) Nor-dehydrodeguelin and nordehydrorotenone, C22 coumaronochromones from Lonchocarpus nicou. Tetrahedron Letters 49: 2407-2409.

30. Kaouadji M (1988) Two new C-prenylated derivatives of 4-dihydroxy benzoic acid from Lonchocarpus nicou roots. Journal of Natural Products 51: 376-378. 